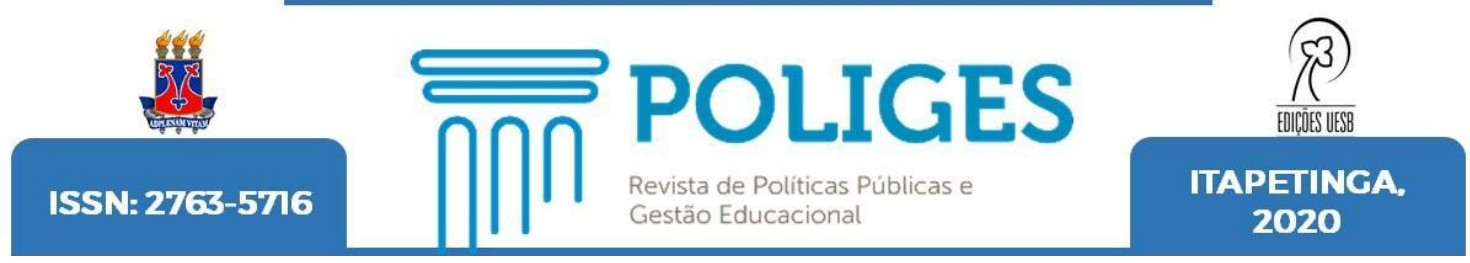

\title{
OS DESAFIOS DO ENSINO REMOTO NA EDUCAÇÃO DO CAMPO
}

\author{
THE CHALLENGES OF REMOTE EDUCATION IN RURAL EDUCATION
}

LOS DESAFÍOS DE LA ENSEÑANZA REMOTA EN LA EDUCACIÓN DEL CAMPO

Luciene Rocha Silva
ORCID iD: https://orcid.org/0000-0002-0403-1117
Mestrado em Educação (UESC) - Diretora do CECLRM (SEC/BA) - Brasil

Arlete Ramos dos Santos

ORCID iD: https://orcid.org/0000-0003-0217-3805

Doutora em Educação (UFMG) - PPGED/UESB/PPGE/UESC - Brasil

Davi Amancio Lima

ORCID iD: https://orcid.org/0000-0001-7770-846X Mestrando em Educação (UESB) - PMVC - Brasil

\begin{abstract}
Resumo: $\mathrm{O}$ artigo trata de uma discussão sobre os desafios no trabalho docente no ensino remoto em tempos de pandemia e toma como base os dados da pesquisa tipo survey originada do projeto "Os desafios enfrentados pelos docentes na utilização das tecnologias educacionais por meio do ensino remoto emergencial nas atividades escolares nos municípios localizados no estado da Bahia, no contexto da pandemia do Covid-19". A referida pesquisa foi realizada entre o período de abril e maio de 2020 e contou com a participação de 756 professores de diversos níveis e modalidades dos sistemas públicos e redes privadas de ensino. Esse trabalho foi realizado pelo grupo de Estudos e Pesquisas Movimentos Sociais, Diversidade Cultural e Educação do Campo e da Cidade -

GEPEMDECC/UESB. A metodologia do projeto, e sob a qual este texto está orientado, fundamenta-se no materialismo histórico dialético, o qual necessita inferir sobre questões subjacentes às realidades que emergem de um cenário histórico, econômico, político e social que incide implícita ou explicitamente na vida dos sujeitos. Como instrumento de coleta de dados utilizou-se um questionário disponibilizado via plataforma eletrônica do Google e aplicado com professores. Os resultados apontam para o registro da investida na proposta de ensino remoto, ao mesmo tempo em que desvelam as fragilidades deste projeto na Educação Básica.
\end{abstract}

Palavras-chave: Educação do campo. Ensino remoto. Políticas públicas 
Abstract: The article deals with a discussion about the challenges in the teaching work in remote education in times of pandemic and takes as a base the data of a survey research stemmed from the project "The impacts of educational technologies utilization by means of distance learning on school activities in cities of Bahia state, on the context of Covid-19 pandemic". The referred research was carried out between April and May of 2020 and had 756 participants among teachers from diverse levels and modalities of public education systems and private tuition institutions. This work was accomplished by a research group named "Grupo de Estudos e Pesquisas Movimentos Sociais, Diversidade Cultural e Educação do Campo e da Cidade" (GEPEMDECC/UESB). The methodology of the project, and that also orients this article, is based on dialectical and historical materialism, that needs to infer on underlying issues to the realities that emerge from a historical, economical, political and social scene that implicitly and explicitly influences on the subjects' life. An online questionnaire available at Google platform was sent to teachers and used to collect data. The results indicate the rise of proposals on distance education and at the same time reveal the fragilities of this project at Basic Education.

Keywords: Public policies. Education in rural areas. Remote teaching.

Resumen: El artículo aborda una discusión sobre los desafíos en la labor docente en educación remota en tiempos de pandemia y toma como base los datos de la encuesta tipo survey originada en el proyecto "Los desafíos que enfrentan los docentes en el uso de tecnologías educativas a través de emergencias enseñanza a distancia en actividades escolares en municipios ubicados en el estado de Bahía, en el contexto de la pandemia Covid-19 ". Esta encuesta se realizó entre abril y mayo de 2020 y contó con la participación de 756 docentes de diferentes niveles y modalidades de sistemas públicos y redes educativas privadas. Este trabajo fue realizado por el Grupo de Estudios e Investigación Movimientos Sociales, Diversidad Cultural y Educación del Campo y la Ciudad GEPEMDECC / UESB. La metodología del proyecto, y bajo la cual se orienta este texto, se basa en el materialismo dialéctico histórico, que necesita inferir cuestiones subyacentes a las realidades que emergen de un escenario histórico, económico, político y social que incide implícita o explícitamente en la vida de los sujetos. Como instrumento de recolección de datos, se utilizó un cuestionario disponible a través de la plataforma electrónica de Google y utilizado con los docentes. Los resultados apuntan al registro de la embestida en la propuesta de educación a distancia, al mismo tiempo que revelan las debilidades de este proyecto en Educación Básica.

Palabras clave: Educación del campo. Enseñanza remota. Políticas públicas

\section{Introdução}

O mundo foi surpreendido em 2019 com uma nova doença contagiosa causada por um tipo de Coronavírus, também conhecido por Covid-19, que se espalha rapidamente pelos países em forma de "Pandemia". O enfrentamento à Covid-19 exige da população, conforme orientação da Organização Mundial da Ano 2020, Volume 1, número 1, set. - dez. de 2020. 
Saúde (OMS), a reclusão social, o uso de máscara, fechamento de escolas, do comércio e de outros setores da economia, além de outros cuidados. Para evitar o contágio da doença, o Ministério de Educação (MEC), através de Portarias $\left(n^{\circ} 343\right.$, de 17/03/2020; $n^{\circ} 345$, de 19/03/2020; $n^{\circ} 473$, de 12/05/2020 e $n^{\circ} 544$, de 17/05/2020), impôs novo modelo de ensino baseado na Educação a Distância, conhecido como ensino remoto, aos sistemas de ensino dos estados e municípios para manter o vínculo dos alunos com a escola. A nova forma de ensinar tem provocado inquietações em professores e alunos devido ao uso das tecnologias no processo educativo, causando reflexos na aprendizagem do aluno e na vida dos docentes em atividade profissional.

Este artigo é um recorte de uma pesquisa intitulada "Impacto da utilização das tecnologias educacionais por meio do ensino remoto nas atividades escolares em municípios baianos, no contexto da pandemia de covid-19", realizada por pesquisadores do Grupo de Estudos e Pesquisas Movimentos Sociais, Diversidade e Educação do Campo e da Cidade (GEPEMDECC) da Universidade Estadual do Sudoeste da Bahia (UESB).

O objetivo deste artigo foi analisar os desafios enfrentados por alunos e professores com o ensino remoto na educação do campo nos diferentes municípios baianos, com observância às estratégias de ensino utilizadas pelos professores na realização das suas atividades pedagógicas, visando assegurar a aprendizagem do aluno e seu envolvimento no ensino remoto.

O método utilizado foi o materialismo Histórico Dialético (MDH), com pesquisa de natureza quali-quantitativa com base no processo exploratório, guiado por documentos originais publicados em sites, com referências bibliográficas, questionários de pesquisa desenvolvidos com o auxílio do Google formulários e distribuídos via online para os professores, gestores e coordenadores pedagógicos, do campo e da cidade, em municípios baianos. O questionário foi respondido por 756 (setecentos e cinquenta e seis) professores da educação básica e superior da Bahia.

O Materialismo Histórico Dialético procura analisar a realidade partindo dos dados empíricos que se apresentam de forma global e difusa, para logo realizar uma desagregação dos dados e estabelecer diferentes conexões e interconexões, 
verificando as múltiplas determinações apresentadas pelo objeto em estudo. Esse método possibilita compreender a realidade quando mediada pelas suas categorias universais, específicas e singulares, visando aproximar o objeto do sujeito pesquisador, dando-lhe clareza e facilitando o seu nível de compreensão no processo de absorção do conhecimento investigado (CUNHA; SOUSA; SILVA, 2014).

Como procedimento metodológico tomamos como base um questionário composto de 36 questões que fora elaborado para a execução da pesquisa e distribuído via e-mail aos sujeitos; os dados obtidos foram posteriormente tabulados e analisados com base nos pressupostos teóricos, dando sustentação às análises, cujo objetivo foi refletir sobre os impactos e os desafios enfrentados por alunos e professores no processo de ensino remoto com a introdução das tecnologias digitais na educação do campo em tempos de pandemia nos municípios baianos pesquisados. Das 36 questões apresentadas extraímos apenas 06 por entender que contribuem para atender os objetivos propostos neste texto e também porque o limite de laudas não nos permite analisar todos os dados coletados pelo questionário.

Sendo assim, a primeira questão escolhida trata do gênero e sexo dos participantes; a segunda trata da iniciativa do ensino remoto no município; a terceira questão refere-se ao envolvimento dos alunos no atendimento às atividades remotas; a quarta reflete as dificuldades enfrentadas pelos alunos com o ensino remoto; a quinta procura saber sobre as estratégias disciplinares do professor no trato pedagógico; e, por fim, a sexta, que verifica quais os recursos mais utilizados para assegurar o ensino remoto com qualidade.

\section{Uma breve análise das pandemias}

O conceito de "pandemia", definido pelo Dicionário online de Português (2020), refere-se a doenças contagiosas e infecciosas que se disseminam por toda uma região; doença que se espalha muito rapidamente e acaba por atingir uma região inteira, um país, continente, etc. Para a Organização Mundial de Saúde (OMS) pandemia é a disseminação mundial de uma nova doença e o termo passa a ser usado quando uma epidemia, surto que afeta uma região, se espalha por

Revista de Políticas Públicas e Gestão Educacional (POLIGES) - UESB-Itapetinga. ISSN: 2763-5716 Ano 2020, Volume 1, número 1, set. - dez. de 2020. 
diferentes continentes com transmissão sustentada de pessoa para pessoa (FIOCRUZ, 2020). Encontramos ainda no referido dicionário uma diferenciação entre as palavras "pandemia" e "epidemia", enfatizando que o termo "pandemia" vem do grego e significa "todo o povo", enquanto "epidemia" simboliza o aumento anormal do número de pessoas contaminadas por uma doença numa determinada região ou país, mas que não toma proporções geográficas maiores (DICIO, 2020). Em dezembro de 2019 o mundo foi surpreendido com a notícia sobre uma epidemia que evoluiu rapidamente para uma Pandemia, causada por um vírus conhecido por Coronavírus ou Covid-19, originário do SARS-COVID II, que teve início na cidade de Wuhan, China, e em seguida se espalhou rapidamente pelo interior do país e para outros países no mundo inteiro, contagiando pessoas de várias idades e sexos, principalmente aqueles que se encontram em situação de risco.

Um dos registros mais longínquos da história foi a epidemia conhecida como a "peste de Xerxes", que foi descrita pelo historiador grego Heródoto (484-420 a.C.), considerado o "pai da História". Dessa vez as cidades gregas contaram com a ajuda das doenças infecciosas para a defesa de seu território (UJVARI, 2003, p.26). A explosão demográfica vivenciada pela Grécia Antiga, sobretudo nas cidades de Atenas e Esparta, principais cidades gregas, trouxe muitos problemas sociais durante o século IV a.C., principalmente em relação à infraestrutura sanitária e às precárias condições de higiene vividas pela população naquele período, propiciando surgimento de vírus contagiosos, colocando a população em risco. Como evidencia em Ujvari (2003):

Em 430 a.C., habitantes de Atenas começaram a apresentar manifestações infecciosas. Rapidamente o número de cidadãos febris aumentou: era o que ficaria conhecido como a epidemia de Atenas, que, partindo da Etiópia para o Egito e a Líbia, chegou ao porto do Pireu numa das numerosas embarcações que ali aportavam. Esse porto, decisivo para o desenvolvimento da cidade, foi também o responsável pela chegada da grande epidemia a Atenas (UJVARI, 2003, p.27).

Além do mundo europeu, a história apresenta registros de surtos pandêmicos em outros continentes, como África e Ásia, que foram atingidos pelos focos de varíola em meados do século XX. A chegada da doença na União Soviética no ano 
de 1958 levou o país a tomar a iniciativa de solicitar à OMS que empreendeu esforços para sua erradicação, pois nessa ocasião a peste da varíola, como era conhecida na época, já era responsável por cerca de dois milhões de óbitos (VERONÉSI, 1992, p. 431).

Os fatos históricos acima relatados nos remetem a uma reflexão: diante do avanço das ciências e das tecnologias, estamos preparados para enfrentar novas pandemias? Será que existe investimento público em pesquisas epidemiológicas? É possível considerar que a desvalorização da ciência expressa seria um motivo para a humanidade ter tanta dificuldade em combater e debelar novos focos de doenças que atingem a população em massa no planeta simultaneamente? Para além disso, em vários países os problemas de saúde pública com impactos têm sido ocasionados, também, pelo avanço desenfreado do capital com a utilização do seu modelo de produção e captação de riqueza, que vem destruindo a natureza e deixando a população em alto nível de vulnerabilidade social (MÉSZÁROS, 2004).

De acordo com o Dr. Artur Gruber (2020), médico e professor do departamento de Parasitologia do instituto de Ciências Biomédicas da Universidade de São Paulo (USP), o Covid-19, também conhecido como Coronavírus devido à família a que pertence e ao seu formato, pode atingir animais e seres humanos, podendo causar sérios danos à humanidade. Em seus relatos ele afirma:

Coronavírus - Vírus da família Coronaviridae causam uma variedade de doenças no homem e nos animais, especialmente no trato respiratório. As partículas virais são esféricas, com cerca de $125 \mathrm{~mm}$ de diâmetro e revestidas por um envelope fosfolipídico. O genoma de RNA de fita simples e senso positivo contém entre 26 a 32 quilobases e está associado a proteínas, formando o nucleocapsídeo. As partículas apresentam projeções que emanam do envelope em forma de espículas, formadas por trímeros da proteína $S$ (spike protein). Essas projeções geram um aspecto de coroa, daí a denominação de Coronavírus (GRUBER, 2020, p. 9).

A pandemia do Covid-19 trouxe prejuízos incalculáveis em várias dimensões:

social, econômica, política e cultural. Só no Brasil, com o isolamento social, $81,9 \%$ dos alunos matriculados na educação básica das redes pública e privada deixaram de frequentar as instituições de ensino, cerca de 39 milhões de pessoas. No planeta esse total soma $64,5 \%$ dos estudantes, o que em números absolutos representa 1,2 bilhão de jovens, crianças e adolescentes fora da escola, segundo dados da

Revista de Políticas Públicas e Gestão Educacional (POLIGES) - UESB-Itapetinga. ISSN: 2763-5716 Ano 2020, Volume 1, número 1, set. - dez. de 2020. 
Unesco (2015); outros milhares de pessoas enclausuradas em seus lares estão alterando hábitos e costumes domésticos e culturais em diferentes setores da sociedade e na vida familiar (BAHIA, 2020).

A crise econômica decorrente do Coronavírus se instalou exigindo o fechamento do comércio, também revelou o tímido investimento em políticas públicas para a saúde, como a falta de equipamentos, leitos e profissionais necessários para salvar vidas contaminadas pela Covid-19. Há, portanto, um novo comportamento social sinalizando os problemas anunciados que exigem dos gestores públicos urgência de políticas sociais, educacionais e econômicas para amenizar os problemas de maior necessidade no mundo atual, como o de salvar vidas (BAHIA, 2020).

Uma análise a respeito do cenário atual sob os impactos da epidemia revela a fragilidade do sistema capitalista, que demonstrou problemas com a economia mundial. Os saldos da crise do capital que vêm se acentuando desde 2008, abalando a economia global, causando guerras comerciais entre as potências mundiais, colapso financeiro, falências de empresas, recessão, o sucateamento da saúde pública, agravaram-se ainda mais com o surto da pandemia da Covid-19. Nesse contexto, demonstra-se que há uma aceleração devido ao

[...] aumento da competitividade e da concorrência intercapitais sem paralelo na era moderna, da força humana que trabalha e a degradação crescente do meio ambiente, da relação metabólica, conduzida pela lógica societal subordinada aos parâmetros do capitalismo e do sistema produtor de mercadorias (MÉSZÁROS, 2011, p 18).

Nas notas editoriais do livro intitulado "O vírus, a Pandemia e o Capitalismo", quando cita as reviravoltas dadas pelo capital para se recompor da crise estrutural, Gauthier (2020) enfatiza que:

[...] O capital em nome da competitividade pressiona países imperialistas por contrarreformas destruidoras dos códigos trabalhistas das pensões no quadro de uma desregulamentação máxima. (...) Em termos econômicos, o Coronavírus se situa ao lado desse terremoto, revelando a fragilidade do sistema capitalista em crises sujeitas a menores imprevistos e reviravolta da situação mundial. [...]. (GAUTHIER, 2020, p.7). 
Portanto, o que a princípio parecia ser uma epidemia, num curto período de tempo ganhou contornos mais complexos e acentuados, desequilibrando a economia global. A pandemia vem mobilizando os mais diversos setores da sociedade, exigindo serviços de saúde e seus equipamentos especializados para salvar vidas em vários países. O mundo foi surpreendido a ponto de algo inédito acontecer em alguns países, a exemplo dos hospitais construídos em dez dias para atender à demanda populacional. As políticas públicas de saúde também demonstraram suas fragilidades no que tange aos investimentos públicos, quando se verifica a carência de profissionais, equipamentos e leitos nos hospitais.

\section{Educação do campo e o ensino remoto}

As políticas de saúde pública, como direito social, têm lugar preponderante na sociedade para garantir o direito à vida, evitando surtos de doenças epidêmicas, mas ainda contam com um grande distanciamento entre o que prevê a lei e a sua efetiva execução. A realidade social revela a falta de investimento público necessário à saúde preventiva, dando lugar ao tratamento curativo de forma ainda precária, visibilizado pelo atendimento público hospitalar que serve à população brasileira.

Os primeiros indícios de políticas de saúde pública no Brasil datam de 1521, quando o rei de Portugal, Dom Manoel, baixou o regimento do Físico-Mor e do Cirurgião-Mor do Reino, instituindo os comissários delegados nas províncias, inclusive no Brasil. Daí por diante podemos enumerar diversos dispositivos legais e instituições para controlar e regular a saúde pública no país, como a criação do Ministério da Saúde em 1953, com o objetivo exclusivo de atender principalmente aos trabalhadores que tinham carteira assinada (UOL, 2020). Mas em 1988, a Constituição Federal determina no marco regulatório de maior relevância da saúde pública para todos os brasileiros, conforme expressa o Art. 196:

A saúde é direito de todos e dever do Estado, garantido mediante políticas sociais e econômicas que visem à redução do risco de doença e de outros agravos e ao acesso universal igualitário às ações e serviços para a sua promoção, proteção e recuperação" (BRASIL, 1988).

Revista de Políticas Públicas e Gestão Educacional (POLIGES) - UESB-Itapetinga. ISSN: 2763-5716 Ano 2020, Volume 1, número 1, set. - dez. de 2020. 
Mesmo com os direitos sociais garantidos pela Constituição Federal (1988), a população brasileira ainda precisa lutar para ter acesso a essas políticas de proteção à saúde devido à falta de investimentos necessários ao atendimento igualitário à saúde pública hospitalar. Sobre a educação, destacamos como uma política pública para a formação humana e, sobretudo, ação que promove o desenvolvimento social, político, econômico e cultural de determinada sociedade.

Como enfatiza Dourado (2007), a educação se constitui

[...] como prática social, portanto, constitutiva e constituinte das relações sociais mais amplas, a partir de embates e processos em disputa que traduzem distintas concepções de homem, mundo e sociedade. [...] a educação é entendida como processo amplo de socialização da cultura, historicamente produzida pelo homem, e a escola, como lócus privilegiado de produção e apropriação do saber, cujas políticas, gestão e processos se organizam, coletivamente ou não, em prol dos objetivos de formação [...] (DOURADO, 2007, p. 923).

A Lei de Diretrizes e Bases da Educação (LDB), n 9.394/96, quando trata da educação básica como direito, prevê modalidades específicas para algumas realidades de ensino, atendendo o ensino para Jovens e Adultos, a Educação Especial e Inclusiva, Educação do Campo, que inclui povos do campo, das águas, das florestas, os povos de quilombos. Portanto, todos os sujeitos do campo e da cidade legalmente têm direito à educação. Entretanto, temos como recorte neste texto uma análise tão somente sobre a Educação do Campo. Os sujeitos que vivem no meio rural trazem em si conhecimentos próprios de sua cultura, de seus hábitos, costumes, suas relações, em suas pertenças que, fortalecidos e preservados, contribuem para o desenvolvimento social e econômico (BRASIL,1996).

O termo Educação do/no Campo é definido por Santos (2013) como aquela educação destinada aos povos camponeses, com formação específica, cujo currículo deve perpassar pelos hábitos, costumes, experiências, relações mútuas vividas e sentidas por estes povos em seus diferentes territórios de identidades. A autora, ao conceber a Educação do Campo, defende a necessidade de uma educação específica que respeite as singularidades dessa população, que habita neste território não apenas como "protetora da terra", como afirma a autora, mas

Revista de Políticas Públicas e Gestão Educacional (POLIGES) - UESB-Itapetinga. ISSN: 2763-5716 Ano 2020, Volume 1, número 1, set. - dez. de 2020. 
também, como os que mantém a terra viva, produtiva, gerando alimentos, também para os que vivem na cidade. Certifica Caldart que há

[...] uma intencionalidade de educar e reeducar o povo que vive no campo na sabedoria de se ver como "guardião da terra", e não apenas como seu proprietário ou quem trabalha nela. Ver a terra como sendo de todos que podem se beneficiar dela aprender a cuidar da terra e apreender deste cuidado algumas lições de como cuidar do ser humano e de sua educação" [...]. Trata-se de combinar pedagogias de modo a fazer uma educação que forme e cultive identidades, autoestima, valores, memória, saberes, sabedoria; que enraíze sem necessariamente fixar as pessoas em sua cultura, seu lugar, seu modo de pensar, de agir, de produzir, uma educação que projete movimento, relações, transformações (2002, p. 37).

As políticas públicas educacionais voltadas para a educação do campo surgem com maior intensidade na agenda política a partir dos anos 1990, com a luta dos movimentos sociais do campo, tendo o Movimento dos Sem Terra (MST) como um dos movimentos sociais protagonistas desse processo mobilizador, elevando a educação recebida pelos camponeses para o campo das políticas públicas educacionais, exigindo uma formação específica para que o homem do/no campo fortaleça a sua identidade. O encontro de professores realizado pelo MST em Brasília, denominado de I Encontro Nacional de Educadores da Reforma Agrária (ENERA), foi considerado o marco da Educação Básica do Campo que, posteriormente, foi sucedido pelas conferências nacionais realizadas sobre Educação do Campo em Luziânia/Goiás, nos anos de 1997 e 1998. Essa mobilização serviu para alavancar a formação inicial e final dos estudantes e reduzir o índice de analfabetismo no campo (SANTOS; CARDOSO; OLIVEIRA, 2017; SANTOS \& SANTOS, 2020).

A Educação do Campo no Brasil, em tempos de pandemia, tem revelado muitas situações que há tempos vêm sendo denunciadas pelos estudiosos e pesquisadores, pelos movimentos sociais, e ainda por aqueles que acompanham de perto o movimento da realidade. Contudo, a miopia social dos que compõem a força de trabalho não permite que a essência dessa realidade se torne evidente devido ao processo de alienação que contamina uma grande parcela de indivíduos que fazem parte dessa base social. Mas percebemos também que há a ocultação dessa realidade pelos meios de comunicação e governantes.

Revista de Políticas Públicas e Gestão Educacional (POLIGES) - UESB-Itapetinga. ISSN: 2763-5716 Ano 2020, Volume 1, número 1, set. - dez. de 2020. 
A falta de atenção e poucos investimentos na educação pública, bastante visíveis neste momento de pandemia, vêm revelando a precariedade $\mathrm{e}$ as dificuldades do acesso e permanência dos estudantes nas escolas em diferentes estados. Tais situações são diariamente denunciadas por meio das pesquisas científicas, pelos movimentos sociais, para assegurar aos sujeitos o direito à educação, de poder permanecer na escola, de modo que esta cumpra a sua missão de educar e formar cidadãos críticos e interventores da realidade social. $\mathrm{O}$ direito à educação está previsto na Constituição Federal (1988) em seu artigo 205, estabelecendo que: "A educação, direito de todos e dever do Estado e da família [...]" (BRASIL, 1988).

Observa-se no governo de Jair Bolsonaro o desmonte das políticas educacionais para os alunos do campo, com destituição de alguns setores - como a Secretaria de Educação Continuada, Alfabetização, Diversidade e Inclusão (SECADI), instalados no Ministério de Educação e Cultura (MEC), que atendiam as demandas educacionais das áreas rurais. De acordo com Souza (2019), conforme informações do portal eletrônico da Andifes, a SECADI, criada em 2004 pelo Decreto n 5.159/2004 durante o governo de Luiz Inácio Lula da Silva e a gestão de Tarso Genro na educação, inicialmente sob a sigla SECAD (Secretaria de Educação Continuada, Alfabetização, Diversidade), posteriormente, com a inserção da política de inclusão, passou a ser conhecida pela denominação atual com vistas a "contribuir para o desenvolvimento dos sistemas de ensino, voltado à valorização das diferenças e da diversidade sociocultural, à promoção da educação inclusiva, dos direitos humanos e da sustentabilidade socioambiental". E desenvolvia ações no campo de "Educação de Jovens e Adultos, Educação Especial na perspectiva inclusiva, Educação Ambiental e em Direitos Humanos, Educação do Campo, Indígena e Quilombola e Educação para as Relações Étnico-Raciais" (SOUZA, 2019).

Com base na extinção da SECADI em 2019, observa-se que o cenário atual vem apontando para um retrocesso político dos sistemas educacionais dos estados e municípios brasileiros, com viés ideológico neoliberal, retomando uma política retrógrada e conservadora aos moldes tradicionais para formação de cidadãos, que se declina para a extinção ou o silenciamento da Educação do Campo, além de

Revista de Políticas Públicas e Gestão Educacional (POLIGES) - UESB-Itapetinga. ISSN: 2763-5716 Ano 2020, Volume 1, número 1, set. - dez. de 2020. 
outros problemas sociais, como a falta de investimento em educação. $O$ analfabetismo funcional e letrado no campo e na cidade afeta consideravelmente a população brasileira em seu processo de desenvolvimento social e econômico (SOUZA, 2019; SANTOS \& NUNES, 2020; SANTOS, 2020a; SANTOS, SOARES \& SOUZA, 2020).

A educação remota não é sinônimo de educação tecnológica, é apenas uma forma de ensino que depende do uso das tecnologias para exercer a sua funcionalidade. Essa forma de ensinar foi pensada para atender aos que estão em isolamento social por causa da pandemia da Covid-19, visa manter o vínculo do aluno com o conhecimento durante o tempo de fechamento da escola. Uma possibilidade encontrada pelo MEC para evitar o rompimento do aluno com a escola e mantê-lo em contato permanente com os seus estudos, procurando evitar o atraso escolar durante a crise da pandemia (BRASIL, 2020).

A educação associada às Tecnologias Digitais de Informações e Comunicação, (TDIC) surge no Brasil com a evolução das tecnologias de ponta no mundo a partir dos anos 1970, sendo possível com o uso da informática. O precursor dessa temática foi Seymour Pápect, que defendia a utilização dos computadores nas escolas para facilitar o aprendizado dos estudantes e o trabalho do professor (SOUSA; FINO, 2018). No momento atual, as tecnologias digitais vêm se aproximando da educação básica de forma rápida e evasiva, legitimada pelo MEC por meio da Portaria MEC/CEB de $n^{\circ} .344$, de 17 de Março de 2020, que regulamenta a substituição das aulas presenciais por aula em meios digitais enquanto durar a pandemia da Covid-19, visando assegurar o vínculo do aluno com a escola, o que vem provocando grandes mudanças no modelo de ensino, conforme está disposto no Art. $1^{\circ}$ que resolve:

Art. 10: Autorizar, em caráter excepcional, a substituição das disciplinas presenciais, em andamento, por aulas que utilizem meios e tecnologias de informação e comunicação, nos limites estabelecidos pela legislação em vigor, por instituição de educação superior integrante do sistema federal de ensino, de que trata o art. $2^{\circ}$ do Decreto $n^{\circ}$ 9.235, de 15 de dezembro de 2017 (BRASIL, 2020).

A Educação a Distância tem origem no grego, do prefixo tele , que significa "longe, ao longe", podendo ser utilizada no processo de ensino-aprendizagem 
mediado por tecnologias, no qual professores e alunos se encontram no mesmo ambiente, porém separados de forma espacial e temporal (HERMIDA; BONFIM, 2006). Assim, a Educação a Distância (EaD) também tem sido considerada como alternativa viável para dar continuidade ao processo de ensino e aprendizagem e para atenuar os impactos em função do distanciamento social, utilizado como principal medida de combate ao vírus. Sobre a EaD, o Art. $1^{\circ}$ do Decreto $n^{\circ} 9.057$ (2017) ressalta:

Art. $1^{\circ}[\ldots]$ considera-se educação a distância a modalidade educacional na qual a mediação didático-pedagógica nos processos de ensino e aprendizagem ocorra com a utilização de meios e tecnologias de informação e comunicação, com pessoal qualificado, com políticas de acesso, com acompanhamento e avaliação compatíveis, entre outros, e desenvolva atividades educativas por estudantes e profissionais da educação que estejam em lugares e tempos diversos. (BRASIL, 2017).

Segundo Belloni (2002), o conceito de EaD é fundamentalmente anglo-saxão, conhecido pelos franceses como "ensino a distância", enfatizando a separação física entre alunos e professores, ou seja, a dimensão espacial e a dimensão da massa de produção e distribuição de bens materiais, que impacta diretamente na acumulação do conhecimento por meio do ensino. A educação como vetor social demanda políticas públicas para maior alcance e êxito no desenvolvimento social.

A educação a distância, enquanto modalidade de ensino voltada para jovens e adultos, atribuída à "educação formal" - aquela legitimada por lei e institucionalizada pelas redes de ensino públicas e privadas -, ainda é pouco valorizada na realidade educacional e vem se aproximando da educação básica, principalmente neste momento de pandemia. Junto com ela, vários problemas referentes à política educacional vêm surgindo, com ênfase no que diz respeito às tecnologias educacionais, que ainda não se fazem presente nos espaços educativos na maioria das escolas da rede pública de ensino, quiçá nas escolas do campo.

A permanência e o avanço da pandemia Covid-19 para os estados e municípios e o alto número de óbitos causados pela doença tornaram o Brasil o epicentro do vírus. O consórcio de veículos de comunicação guiado pelas informações oficiais informa que mais 280 mil pessoas, até a data da escrita deste

Revista de Políticas Públicas e Gestão Educacional (POLIGES) - UESB-Itapetinga. ISSN: 2763-5716 Ano 2020, Volume 1, número 1, set. - dez. de 2020. 
texto (17/03//2021), foram mortas pela doença, e um quantitativo acima dos 11 milhões de pessoas infectadas, posicionando o Brasil numa escala abaixo dos Estados Unidos entre o grupo dos 215 países com 11,6 milhões de pessoas que lutam contra o vírus (BOLETIM DA COVID.19 - BAHIA, 2021).

A fim de manter o vínculo escolar com a comunidade evitando o contágio da doença, uma vez que as escolas são frequentadas por milhares de crianças, jovens e adolescente em idade escolar, uma Portaria foi editada pelo MEC, a de $\mathrm{n}^{\circ} 544$, de 16 de junho de 2020, que substitui as aulas presenciais por aulas com meios digitais, enquanto durar a situação da pandemia pelo novo Coronavírus - Covid-19, revogando, portanto, as Portarias anteriores, quais sejam: a Portaria $n^{\circ} 343$, de 17 de março de 2020, que suspende aulas presenciais e adota aulas digitais, autorizando o uso das tecnologias para orientação das disciplinas escolares; a Portaria $n^{\circ} 345$, de 19 de março de 2020, que revoga a primeira, alterando o seu conteúdo, quando substitui o atendimento presencial das disciplinas em andamento por aulas digitais; e ainda a de $n^{\circ} 473$, de 12 de maio de 2020, que prorroga o prazo previsto na Portaria $n^{\circ} 343$, em seu artigo $1^{\circ}$, dispondo que na portaria do MEC de $n^{\circ}$ 473/2020 em seu Art. $1^{\circ}$ "Fica prorrogado, por mais trinta dias, o prazo previsto no $\S$ $1^{\circ}$ do art. $1^{\circ}$, da Portaria $n^{\circ} 343$, de 17 de março de 2020"(BRASIL,2020). Assim como a Portaria, de $n^{\circ} 544$ de 17 de junho de 2020, a qual se refere à substituição das aulas presenciais por aulas em meios digitais enquanto durar a situação de pandemia e revoga as portarias anteriores. Por fim temos a Resolução CNE/CP de $\mathrm{n}^{\circ}$ 14.040/2020, de 18 de agosto de 2020, que autoriza aos sistemas de ensino brasileiros a reordenar o currículo escolar e reprogramar para o ano letivo de 2021, com aprovação automática. Sendo assim, o currículo da Educação Básica não implementado no ano letivo de 2020 será ministrado em caráter excepcional no ano de 2021, sob a lógica de um continuum curricular de dois anos, (o aluno fará dois anos em um), observadas as diretrizes curriculares editadas pelo CNE, a Base Nacional Comum Curricular (BNCC) e as normas dos respectivos sistemas de ensino. Que será trabalhado com uma carga horária de 1.600 horas total durante o biênio (COSTA, 2020).

Ainda não se pode prever o desfecho final dessas medidas governamentais de prevenção à saúde pública no país. Até o momento, não se tem vacinas

Revista de Políticas Públicas e Gestão Educacional (POLIGES) - UESB-Itapetinga. ISSN: 2763-5716 Ano 2020, Volume 1, número 1, set. - dez. de 2020. 
suficientes para uma vacinação em massa da população no combate ao novo Coronavírus - Covid-19, que já se encontra na segunda onda em quase todo o mundo. Enquanto isso, nossos estudantes da Educação Básica sofrem com a desigualdade digital, uma vez que as escolas não estão aparelhadas com as tecnologias educacionais para atender os alunos da rede pública, principalmente aquelas localizadas em zona rural e em bairros periféricos urbanos. Santos e Nunes (2020) informam por meio de suas pesquisas que aqueles estudantes que ocupam esses espaços territoriais não possuem internet potente, celulares, tabletes e/ou computadores com memória necessária que permita receber ou baixar arquivos pesados para facilitar seus estudos, atendendo às exigências das secretarias municipais e estaduais de educação do país mediante a instituição legal do ensino remoto.

\section{Educação em tempos de pandemia em municípios baianos: impactos e desafios}

A chegada da Pandemia em diferentes municípios baianos levou as Secretarias de Educação (estadual e algumas municipais) a implementar a educação remota para os alunos matriculados no ensino Fundamental e Educação Infantil, promovendo fortes reflexos de desigualdade no atendimento educacional nas escolas do campo. Com base nos dados coletados na pesquisa que realizamos no GEPEMDECC/CNPq, apresentaremos aqui os resultados da aprendizagem efetiva desses estudantes e os desafios enfrentados pelos professores com o ensino remoto.

Verificando os resultados de proficiência nas escolas retomamos algumas questões básicas. Qual o índice de aprendizagem que vai atingir os alunos no período pós-pandemia com o ensino remoto? Qual o impacto desse ensino na educação básica do $1^{\circ}$ ao $9^{\circ}$ ano do Ensino Fundamental? Que desafios serão enfrentados pelos docentes na execução do ensino remoto? Essas e outras reflexões merecem atenção dos estudiosos, que poderão encontrar respostas por 
meio de pesquisas cujos resultados, sistematizados e articulados com as teorias pedagógicas e de conhecimentos, servirão para explicar a realidade concreta.

A Bahia, como lócus desta pesquisa, é um dos estados federativos mais antigos do Brasil, está localizada na região Nordeste, com uma área territorial de $564.760,467 \mathrm{~km}^{2}$ onde vivem pouco mais de 14 milhões de habitantes (IBGE, 2019). Possui uma ampla e complexa rede educacional composta pelo Ensino Superior, Educação Básica e ensino técnico profissionalizante. Além do Ensino Superior e do Ensino Médio, a Secretaria Estadual de Educação da Bahia ainda se responsabiliza pelo Ensino Fundamental (anos finais, $6^{a}$ ao $9^{\circ}$ ano) na maioria dos municípios baianos. Na educação básica, até o ano de 2018, contava com 2.034.077 alunos matriculados nos anos finais do Ensino Fundamental ( $6^{\circ}$ ao $9^{\circ}$ ano), enquanto no Ensino Médio abarcava apenas 566.952 alunos, entre jovens e adultos matriculados nas escolas da rede. Para o atendimento educacional a Secretaria de Educação e Cultura (SEC/BA) possui 105.266 docentes para o trabalho com o Ensino Fundamental e 31.397 professores exercendo suas funções com o Ensino Médio. Ao todo são 14.081 escolas para atender o ensino fundamental, número que contrasta com 1.577 estabelecimentos de Ensino Médio. Portanto, o estado da Bahia compõe uma rede de ensino extensa e com muitas complicações nas suas especificidades educacionais (IBGE, 2019).

O primeiro dado analisado se refere à questão de gênero/sexo dos sujeitos participantes da pesquisa. Conforme os resultados determinam, o público feminino é o que predomina na profissão do magistério, e verifica-se preponderância de $80 \%$ do sexo feminino e de apenas $20 \%$ do sexo masculino. Evidencia-se que o espaço escolar no Ensino Fundamental é ocupado pela maioria de mulheres. É um trabalho direcionado à educação dos indivíduos na formação da cidadania que envolve não apenas o público adulto, mas sobretudo crianças e adolescentes, o que exige habilidades e conhecimentos teóricos, pedagógicos e didáticos. O número de homens que atuam nessa profissão ainda é pouco expressivo na atualidade, mesmo com a demonstração de elevação dos dados da participação masculina no exercício da docência. No século XX a docência tomou a condição de espaço eminentemente feminino, revelando-se atualmente uma atividade profissional com presença 
significativamente maior no contingente de mulheres, certificado pelos dados do INEP (2007) quando afirma que:

Nas creches, na pré-escola e nos anos iniciais do ensino fundamental, o universo docente é predominantemente feminino (98\%, 96\% e 91\%, respectivamente). No entanto, a cada etapa do ensino regular amplia-se a participação dos homens, que representam $8,8 \%$ nos anos iniciais do ensino fundamental, $25,6 \%$ nos anos finais e chegam a $35,6 \%$ no ensino médio. [...] Não obstante, se consideradas todas as etapas e modalidades da educação básica, $81,6 \%$ dos professores que estavam em regência de classe são mulheres e somam mais de um milhão e meio de docentes - 1.542.925 (INEP, 2007, p 23).

A iniciativa do ensino remoto regulamentado pelo Ministério da Educação pela Resolução do MEC/CNE de $n^{\circ}$ 14.40/2020, que autoriza os estados e municípios a tomarem decisões que mantenham o vínculo com a escola. Lembramos que a nossa pesquisa foi realizada por meio do questionário elaborado no formulário do Google forms aplicado para professores das redes pública e privada, na qual tivemos 756 respondentes. Salientamos que no período de aplicação dos questionários um número significativo de municípios ainda não estava realizando o ensino remoto. Dentre os sujeitos, $70 \%$ se identificaram como oriundos da educação básica pública; $21,56 \%$ são da rede estadual de ensino; $12,96 \%$ são da rede privada; e por fim, 3,44\% se identificaram como pertencentes à rede federal. Ao tratar sobre a iniciativa da educação remota, nos surpreendemos com as respostas dadas pelos interlocutores. Um percentual de 23,9\% (181) dos sujeitos interrogados disseram que ministram o ensino remoto e que a iniciativa foi da escola; outros $27.9 \%$ (211) informam que o novo modelo de ensino com o uso das tecnologias foi adotado pela Secretaria de Educação, visando manter o aluno em contato como os estudos, e ainda atribuem ao poder público a responsabilidade da iniciativa para o ensino remoto nas escolas. Há ainda aqueles que representam um percentual de 8,7\% (66), os quais afirmam que a inciativa do ensino remoto no município partiu do professor. Um número expressivo, equivalente a 34,92\% (264), assinalou a alternativa "não se aplica" (tendo em vista os vários municípios que ainda não se decidiram por utilizar o ensino remoto), e um quantitativo pequeno de professores, cerca de 4,5\% (34), não expressou opinião sobre a atual situação com o ensino remoto no município.

Revista de Políticas Públicas e Gestão Educacional (POLIGES) - UESB-Itapetinga. ISSN: 2763-5716 Ano 2020, Volume 1, número 1, set. - dez. de 2020. 
Sobre a participação dos alunos nas atividades remotas oferecidas pela escola, averiguamos que 26,06\% (197) dos questionados afirmam que os alunos responderam bem à iniciativa da escola em aplicar atividades remotas. Nesse sentido, uma das leituras possíveis a partir dos dados colhidos é que muitos alunos já possuem um domínio funcional de certas tecnologias digitais, algo que pode estar relacionado com o grande contato desses alunos com as redes sociais, uma vez que estas já Ihes são acessíveis por meio das aplicativos como Whatsapp, Facebook, Instagram, além de outros. Mas um número expressivo de alunos apresentou dificuldades em atender totalmente às atividades encaminhadas pelos professores, pois cerca de 38,86\% (256) dos que responderam ao questionário afirmam que os alunos atendem parcialmente às atividades que lhes são direcionadas pela escola e $37,83 \%$ (286) informaram que não se aplica.

Esse percentual expressivo acima citado de alunos que respondem às atividades revela que mesmo dispondo de uma ferramenta tecnológica, um indivíduo pode ainda estar separado dela. Além do mais, esse comportamento denota que alunos e professores ainda não se adequaram à experiência inédita do ensino remoto e que o ato de aprender é muito mais complexo do que simplesmente transmitir conhecimentos. O ensino remoto evidencia a necessidade de se reconstituir no mundo online todas as relações e as estruturas de apoio à escola (CASATTI, 2020). O problema não está na utilização das tecnologias, mas no uso que se faz desse recurso como um aparato pedagógico obrigatório nas escolas em tão pouco tempo.

Ao questionar sobre as dificuldades enfrentadas pelos alunos para terem acesso às tecnologias obtivemos os seguintes resultados: cerca de 23,63\% (179) dos sujeitos responderam que os alunos não possuem internet em casa; 4,89\% (37) não têm habilidade com o uso das tecnologias; 9,39\% (71) compartilham seus equipamentos com os colegas para ter acesso às atividades remotas; $8,73 \%$ (66) afirmam que os seus educandos não respondem às atividades por alegarem internet de baixa qualidade e velocidade; contudo, 30,68\% (300) informaram que não estão tendo o ensino remoto. O cenário reflete a falta de investimento em políticas educacionais tecnológicas nas escolas do campo e da cidade, o despreparo dos profissionais da educação em lidar com o ensino remoto, além da ausência de uma

Revista de Políticas Públicas e Gestão Educacional (POLIGES) - UESB-Itapetinga. ISSN: 2763-5716 Ano 2020, Volume 1, número 1, set. - dez. de 2020. 
conduta cotidiana na utilização de aparelhos tecnológicos para o estudo escolar, bem como a ausência de acompanhamento no processo educativo por parte de membros da família, instigando os seus filhos na aquisição de autonomia e responsabilidades pelas suas tarefas escolares. Essa ausência de interesse pelos assuntos da escola tem suas raízes em um estranhamento daquilo que deveria ser primordial para sua constituição, que é a educação, pois ao invés de ser algo que lhe emancipa agora, Ihe traz tédio ou angústia; desta maneira os alunos, ao invés de se perceberem como sujeitos protagonistas, parecem estar à margem da história (CASATTI, 2020).

Além disso, esse indivíduo ainda tem algo em comum com uma fatia social considerável da população da Bahia: faz parte de um grupo social que não possui recursos financeiros necessários para obtenção de equipamento para realizar as atividades do ensino remoto. Essa disparidade social, que é própria do sistema capitalista, provoca uma acentuada desigualdade social e a exclusão digital naqueles com menor poder aquisitivo, segregando por raça e gênero.

Ao analisar as questões que tratam das atividades realizadas pelo professor no âmbito do ensino remoto, referindo-se ao material organizado e às atividades realizadas com seus alunos, verifica-se uma preponderância do trabalho com os conteúdos disciplinares, pois cerca de 44,84\% (330) dos professores se apegam aos livros didáticos para desenvolver suas atividades escolares. Em contraste com $42,46 \%$ (321) dos participantes, que trabalham com temas mais atuais como pandemia, economia, desemprego, passando por uma formação que contemple a realidade social, o que contribui para a formação do pensamento crítico, traduzindo a aplicabilidade de uma pedagogia progressista ao invés de uma postura mercadológica por parte do professor, alinhada aos ditames do capital como uma forma de reprodução do poder da sua ideologia.

Socializar, portanto, a educação é provocar ruptura com a postura alienada para a necessidade real dos sujeitos da educação, de modo que faça emergir uma melhor preparação para a vida em sociedade. Como evidencia Mészáros (2008, p 48), "Apenas a mais ampla das concepções de educação nos pode ajudar a perseguir o objetivo de uma mudança verdadeiramente radical, proporcionando instrumentos de pressão que rompam a lógica mistificadora do capital". Os dados

Revista de Políticas Públicas e Gestão Educacional (POLIGES) - UESB-Itapetinga. ISSN: 2763-5716 Ano 2020, Volume 1, número 1, set. - dez. de 2020. 
evidenciaram que $42 \%$ dos entrevistados afirmam aplicar atividades envolvendo temas atuais, demonstrando uma postura pedagógica mais crítica e inovadora, adotando abordagens temáticas com possibilidades de novas experiências; cerca de $48 \%$ não responderam e, finalmente, $0.5 \%$, não deve ter entendido bem a questão, solicitando esclarecimento e especificação.

Apresentamos uma questão sobre a adesão dos alunos às atividades remotas, cujos dados constataram que $5 \%$ dos professores consideraram péssima, $10 \%$ consideram ruim, $42 \%$ consideram regular e apenas $10 \%$ disseram que é ótima, enquanto $35 \%$ destes preferiram se abster. Os resultados são preocupantes, uma vez que se juntarmos o número de alunos com participação regular, ruim e péssima com o número de alunos que se absteve de fazer as atividades remotas, somam-se $85 \%$. Esse dado revela que a maioria dos alunos não apresentava habilidades necessárias ou interesse para o trabalho com atividades que envolvem as tecnologias educacionais. Apenas $15 \%$ dos estudantes encontram-se com condições para participar do ensino remoto. Esse dado pode ser um indício expressivo daquele que é o retrato da educação do Brasil, um sistema educacional que ainda necessita de muita atenção por parte do poder público.

Santos (2019, p. 65), em suas análises sobre a política do Programa Nacional de Tecnologia Educacional (Prolnfo) no ensino fundamental, relata que as escolas do campo ainda sofrem com os poucos investimentos públicos na educação e que isso se reflete no trato das tecnologias educacionais, conforme demonstram os dados estatísticos enfatizando que:

[...] O Censo Escolar de 2015 divulgado pelo Instituto Nacional de Estudos e Pesquisas (Inep), aponta que apenas 24\% das 58.874 escolas brasileiras existentes no campo têm acesso à internet e computador. Em áreas urbanas são 53.519 escolas, no entanto $91 \%$ destas têm acesso à internet e computador. Os dados expõem a dura realidade, a política pública foi implantada mas, falta ainda um longo percurso para poder atender o público destinado, considerando os números, a política não se efetiva na íntegra e em relação às áreas urbanas as comunidades camponesas continuam desassistidas (SANTOS; GARCIA; SANTOS, 2017, p. 657).

Como explicita Santos (2019) e Santos (2020b), as tecnologias não devem ser usadas apenas como ferramenta pedagógica para auxiliar no processo de ensino

Revista de Políticas Públicas e Gestão Educacional (POLIGES) - UESB-Itapetinga. ISSN: 2763-5716 Ano 2020, Volume 1, número 1, set. - dez. de 2020. 
remoto, mas como um instrumento de intervenção no processo de formação do indivíduo na construção de uma sociedade igualitária e democrática, capaz de produzir pensamentos críticos. Portanto, há necessidade de pessoas qualificadas para o trabalho com o uso das tecnologias que envolvem a Educação a Distância. Infelizmente, a educação pública é carente de formação, recursos e de políticas educacionais tecnológicas que assegurem um ensino remoto com resultados satisfatórios nas escolas em tempos de pandemia.

\section{Breves considerações}

Os impactos negativos da pandemia da Covid-19 não se manifestam apenas como um problema epidemiológico para os 215 países atingidos, mas também, revelam os problemas estruturais por que passam os países que necessitam de mais investimentos em todas as áreas, inclusive na política educacional, como é o caso do Brasil. Segundo dados do Dieese (2020), a pandemia do coronavírus afastou mais de 1,5 bilhão de alunos matriculados nas escolas públicas em diferentes países afetados; só nas escolas públicas brasileiras são 35,7 milhões de alunos, um contingente de estudantes da educação básica bastante expressivo que merece atenção do poder público, em especial no tocante aos cuidados com a vida do ser humano. O ensino remoto no Brasil, autorizado pelo MEC por meio de Portarias como estratégia para manter o vínculo do aluno com a escola, não surtiu muito efeito para os alunos da rede pública estadual e municipal.

Os resultados da nossa pesquisa apontam que os professores ainda não apresentaram as competências necessárias para o trabalho com o ensino remoto, com o uso das tecnologias utilizaram-nas apenas como uma ferramenta pedagógica, trocando o quadro de giz, pelos recursos tecnológicos com o Whatssapp, vídeo aula e o livro didático como recurso pedagógico básico. Muitos alunos não conseguiram se adaptar ao ensino remoto, não atendendo às atividades encaminhadas pela escola, pois cerca de $85 \%$ deles não deram devolutivas aos professores, denotando um distanciamento em relação aos assuntos inerentes à escola. Outras revelações são as dificuldades de acesso da maioria dos alunos, por não terem aparelhos de

Revista de Políticas Públicas e Gestão Educacional (POLIGES) - UESB-Itapetinga. ISSN: 2763-5716 Ano 2020, Volume 1, número 1, set. - dez. de 2020. 
celulares ou computadores com capacidade de memória necessária para atender suas necessidades de estudos ou pela ausência desses equipamentos tecnológicos em suas residências. A falta de condições das famílias de baixa renda as impede de atender as necessidades educativas que possibilitam a ampliação do conhecimento dos seus filhos. Além da impossibilidade ao acesso tecnológico, nota-se a dependência física do aluno com a escola, e, consequentemente, a falta de autonomia para prover sua formação intelectual em seu processo de escolarização sem o auxílio do professor. Por fim, o ensino remoto revela a fragilidade da escola no processo de ensino e aprendizagem, como o uso das tecnologias, a falta de preparo da maioria dos docentes que ainda não dominam as ferramentas tecnológicas educacionais e as necessidades de mais investimentos dessa política para equipar as escolas e propiciar formação aos educadores.

\section{Referências}

BAHIA. Secretaria Estadual de Saúde, Governo do Estado da Bahia. Boletim Informativo sobre o coronavirus-COVID-19. Bahia, $\mathrm{n}^{\circ}$ 69. 2020. Disponível em <www.boletimeletronico.ba.gov.br>. Acesso em: 17 jul .2020.

BAHIA. Secretaria Estadual de Saúde, Governo do Estado da Bahia, Boletim Informativo sobre o Coronavírus- COVID-19. Disponível em www.boletimeletronico.ba.gov.br>. Acesso, 17/03/2021.

BELLONI. Maria Luiza. Ensaio sobre a educação a distância no Brasil. Educ. So , Campinas, v. 23, n. 78, p. 117-142, abril de 2002. Disponível em: $<$ http://www.scielo.br/scielo.php?script=sci_arttext\&pid=S0101-73302002000200008 \&lng=en\&nrm=iso>. Acesso em: 31 jul. $20 \overline{20}$.

BRASIL. [Constituição (1988)]. Constituição da República Federativa do Brasil. Diário Oficial da União, n 191-A. Brasília, DF: 05 out. 1988. Senado Federal. Disponível em: <http://www.planalto.gov.br/ccivil_03/constituicao/constituicao.htm> Acesso em: 15 ago. 2020.

BRASIL. Decreto Lei de n. 9.057 de 25/05/2017. Regulamenta o Art. 80 da Lei ${ }^{\circ}$ 9.394, de 20 de dezembro de 1996, que estabelece as Diretrizes e Bases da Educação Nacional. Diário Oficial da União, n n¹00. Brasília, DF, 26 mai. 2017. Disponível em: <http://www.planalto.gov.br/ccivil_03/_ato2015-2018/2017/decreto/d9057.htm> Acesso em: 23 ago. 2020. 
BRASIL. Lei n 9.394, de 20 de dezembro de 1996. Estabelece as Diretrizes e Bases da Educação Nacional. Diário Oficial da União. Brasília, DF: 23 dez. 1996.

Ministério da Educação e Cultura. Disponível em:<http://www.planalto.gov.br >. Acesso em: 20 jul. 2020.

BRASIL. Portarias n 343 de 17 de março de 2020. Dispõe sobre a substituição das aulas presenciais por aulas em meios digitais enquanto durar a situação de pandemia do Novo Coronavírus - COVID-19. Diário Oficial da União, edição 53, seção 1, p.39. Brasília, DF: 18 mar. 2020. Disponível em:

<www.in.gov.br/web/dou/-/portaria-n-343-de-17-de-março-de-2020>. Acesso em 17 de julho de 2020.

BRASIL. Portarias n. 345 de 19 de março de 2020. Altera a Portaria MEC n³43, de 17 março de 2020. Diário Oficial da União, $n^{\circ} 54$, seção 1, p. 1. Brasília, DF: 2020. Disponível em

<http://www.in.gov.br/web/dou/-/portaria-n-345-de-19-de-marco-de-2020>. Acesso em: 17 jul. 2020.

BRASIL. Portarias 473 de 12 de maio de 2020. Prorroga o prazo previsto no $\S 1^{\circ}$ do art. $1^{\circ}$ da Portaria $n^{\circ} 343$, de 17 de março de 2020. Diário Oficial da União, $n^{\circ} 90$, seção 1, p. 55. Brasília, DF: 13/05/2020. Disponível em:

<www.in.gov.br/web/dou/-/portaria-n-473-de-12-de-maio-de-2020>. Acesso em 17 jul. 2020.

BRASIL. Portarias 544 de 16/06/2020. Dispõe sobre a substituição das aulas presenciais por aulas em meios digitais, enquanto durar a situação de pandemia do novo Coronavírus - Covid-19, e revoga as Portarias MEC n 343, de 17 de março de 2020, $n^{\circ} 345$, de 19 de março de 2020, e n 473, de 12 de maio de 2020. Diário Oficial da União, $n^{\circ}$ 144, seção 1, p. 62. Brasília, DF: 17/06/2020. Disponível em: <www.in.gov.br/web/dou/-/portaria-n-544-de-17-de-junho-de-2020>. Acesso em 17 jul. 2020.

BRASIL. Lei MEC/CNE $\mathbf{n}^{\circ}$ 14.040. Estabelece normas educacionais excepcionais a serem adotadas durante o estado de calamidade pública, reconhecido pelo Decreto Legislativo $n^{\circ} 6$, de 20 de março de 2020; altera a lei de $n^{\circ} 11497$, de 16 de Junho de 2009.

CALDART, Roseli Salete. Pedagogia do Movimento Sem Terra: Escola é mais do que escola. $2^{\mathrm{a}}$ ed. editora Vozes, Petrópolis/RJ, 2002.

CASATTI. Denise. Um guia para sobreviver a pandemia no ensino remoto. Instituto de Ciências Matemáticas e de Computação (ICMC) Universidade de São Paulo. São Carlos, SP, 2020. Disponível em: <https://www icmc/usp.gov.br.> Acesso em 27 jul., 2020.

COSTA. Lígia. As aulas remotas continuarão em 2021? Entenda a Resolução do Conselho Nacional de Educação. Diário do Nordeste, escrito em 19/10/2020.

Revista de Políticas Públicas e Gestão Educacional (POLIGES) - UESB-Itapetinga. ISSN: 2763-5716 Ano 2020, Volume 1, número 1, set. - dez. de 2020. 
Disponível em:< https:// www.diariodonordeste.verdesmares.com.br>, Acesso em 18 de mar de 2021.

CUNHA. Célio da. SOUSA, José Vieira. SILVA, Maria Abádia. (orgs), O Método Dialético na Pesquisa em Educação. Campinas, SP: Autores associados, 2014. Coleção Políticas Públicas de Educação.

DICIO. Dicionário Online de Português. Verbete "Epidemia". Dicio - Dicionário online de Português. 2020. Disponível em: <https://www.dicio.com.br/pandemia/.>. Acesso em 27 ago. 2020.

DICIO. Dicionário Online de Português. Verbete "Pandemia" Dicio - Dicionário online de Português. 2020. Disponível em: <https://www.dicio.com.br/pandemia/.>. Acesso em 27 ago. 2020.

DOURADO. Luiz Fernandes (Org.) Plano Nacional de Educação (2011-2020): avaliação e perspectivas. $2^{\circ}$ ed. Goiânia: Editora da UFG. Brasília: Autêntica Editora, 2007.

FIOCRUZ. Fundação Oswaldo Cruz. Ministério da Saúde. Instituto Tecnológico de Imonobiológicos - BIOMANGUINHOS. Disponível em internet. Acesso em $17 / 032021$.

GAUTHIER. Lucien. O vírus, a Pandemia e o Capitalismo - Notas editoriais da revista A Verdade 105. O Trabalho. [S.I], 2020. Disponível em:

<http://otrabalho.org.br.>. Acesso em 12 jul. 2020.

GRUBER. Artur, Covid-19: o que se sabe sobre a origem da doença. Jornal da USP. São Paulo, 14/04/2020. Disponível em: <https:/www./jornal.usp.br>. Acesso em: 18 jul. 2020.

HERMIDA. Jorge Fernando; BONFIM, Cláudio Ramos de Souza Bonfim. Educação à Distância: História, Concepções e Perspectivas. Revista HISTEDBR online, Campinas SP, n. especial, p. 166-181, ago. 2006. Disponível em: <http://www.histedbr.fe.unicamp.br >. Acesso 27 ago. 2020.

IBGE. Censo Escolar 2018. Brasil/Bahia/cidades. Instituto Brasileiro de Geografia Estatística. Brasília, DF, 2019. Disponível em:

<https://cidades.ibge.gov.br/brasil/ba/pesquisa/13/78117. >. Acesso em 31 jul. 2020. INEP. Censo do Professor. Instituto Nacional de Educação e Pesquisa.Brasília, DF,2007. Disponível em https://www.portaldomec.gov.br>. Acesso em 25 jul. 2020.

MARQUES. Ronualdo. A ressignificação da educação e o processo de ensino e aprendizagem no contexto de pandemia da COVID-19. Boletim da Conjuntura BOCA, Boa Vista, vol. 03, nº 07, Ano II, p. 31-46, jul. 2020. Disponível em $<$ <ttp://www.revista.ufrr.br/boca.>. Acesso em 23 jun. 2020.

Revista de Políticas Públicas e Gestão Educacional (POLIGES) - UESB-Itapetinga. ISSN: 2763-5716 Ano 2020, Volume 1, número 1, set. - dez. de 2020. 
MÉSZÁROS, Istvan, O Poder da Ideologia. Tradução: Paulo Cesar Castanheira. São Paulo, SP: Boitempo Editorial, 2004.

MÉSZÁROS, Istvan A educação para além do Capital. São Paulo: Boitempo Editorial, 2008.

MÉSZÁROS, Istvan. Para Além do Capital: rumo a uma teoria de transição. Tradução Paulo César Castanheira, Sérgio Lessa. $1^{a}$ ed. São Paulo: Led revista, Boitempo, 2011.

SANTOS, Eliane Nascimento dos. A política de Laboratórios de Informática em Escolas do Campo do ensino fundamental: estudo do Prolnfo no Município de Vitória da conquista/BA. 2019. 260 p. Dissertação de Mestrado (Programa de Pós-Graduação em Ensino - PPGEN/UESB) - Universidade Estadual do Sudoeste da Bahia, Vitória da Conquista, 2019.

SANTOS, Eliane Nascimento dos; GARCIA Fátima M.; SANTOS, Vanessa C.

Tecnologia Educacional em Escolas do Campo: como este Direito se materializa. In: Congresso Interinstitucional Brasileiro de Educação Popular e do Campo CIBEPOC, 2017, Catalão, Goiás. Anais... Eixo 4 - História e Memória das escolas populares e rurais. Goiás: Universidade Federal de Goiás (UFG), 2017, p. 653-667, Disponível em: <congressos.sistemasph.com.br/index.>. Acesso em 27 ago. 2020.

SANTOS, Arlete Ramos dos.; NUNES, Cláudio Pinto. Reflexões sobre políticas educacionais para campo brasileiro. Editora Edufba : Salvador-Ba. 2020.

SANTOS, Igor Tairone Ramos dos. Avaliações que educam: um estudo sobre avaliação formativa mediada por tecnologias digitais no Instituto Federal da Bahia. 2020. 139 f. Dissertação (Mestrado) - Curso de Pós-Graduação em Educação, Universidade Estadual do Sudoeste da Bahia, Vitória da Conquista, 2020b.

SANTOS, Valéria Prazeres dos.; SANTOS, Arlete Ramos dos. Relação entre a distorção idade-série nas escolas do campo e as políticas de avaliação. Revista De Estudos Em Educação E Diversidade - REED, 1(2), 166-184. 2020. https://doi.org/10.22481/reed.v1i2.7687

SANTOS, Arlete R. dos. Internacionalização da pesquisa e produção do conhecimento sobre educação do campo da área da educação na região Nordeste (2013-2020). Práxis Educacional, 16(43), 196-228. 2020a.

https://doi.org/10.22481/rpe.v16i43.7689

SOUSA. Jesus Maria; FINO, Carlos Nogueira. As TIC abrindo caminhos para novos paradigmas educacionais. Educação e Cultura Contemporânea, Rio de Janeiro, v. 5, $\mathrm{n}^{\circ} 10$, p. 11-16, primeiro semestre de 2008, Disponível <https://www.google.com/SOUSA.Jesus+Maria.>. Acesso em 23 jul. 2020.

Revista de Políticas Públicas e Gestão Educacional (POLIGES) - UESB-Itapetinga. ISSN: 2763-5716 Ano 2020, Volume 1, número 1, set. - dez. de 2020. 
SANTOS, A. R. dos, SOARES, J. de S., \& SOUZA, E. Q. de Educação do Campo como categoria temática em revistas (2015-2020). Revista Exitus, 10(1). 2020. https://doi.org/10.24065/2237-9460.2020v10n1ID1459

SOUZA. Marciana Freitas de. A extinção da SECADI e o campo da Educação na Conjuntura atual. Justificando, [S.I], 17 jan. 2019. Disponível em:

<http://www.justificando.com. . . Acesso em 18 jul. 2020.

UJVARI, Stefan Cunha. A história e suas epidemias: A convivência do homem com os microrganismos. Rio de Janeiro/RJ: Senac Rio. São Paulo/SP: Senac São Paulo, 2003. 311p.

UNESCO. Relatório de ciências da Unesco Rumo a 2030: visão Geral e cenário brasileiro. União das Nações Unidas para Educação, a Ciência e a Cultura. Brasil: Edições Unesco, 2015. Disponível em: <www.unesco.gov.br.com.>. Acesso em 25 jul. 2020.

UOL, Coronavírus. Universo Online Disponível em<https://www.uol.com.br/saude. Acesso em 17 jul. de 2020.

VERONESI, Ricardo et al. Doenças infecciosas e parasitárias. $8^{a}$ ed. Editora Rio de Janeiro: Guanabara Koogan, 1992.

\section{Luciene Rocha Silva}

Mestre em Educação (UESC). Colégio Estadual do Campo Lúcia Rocha - Brasil

\section{Arlete Ramos dos Santos}

Doutora em Educação (UFMG), Pós-doutorado em Educação e Movimentos Sociais pela UNESP; Professora Titular o DCHEL/UESB; Profa. do PPGED/UESB e do PPGE/UESC Brasil.

\section{Davi Amancio Lima}

Mestrando em Educação (UESB) - Psicólogo e servidor público na Prefeitura Municipal de Vitória da Conquista - PMVC - Brasil. 
Revista de Políticas Públicas e Gestão Educacional (POLIGES) - UESB-Itapetinga. ISSN: 2763-5716 Ano 2020, Volume 1, número 1, set. - dez. de 2020. 